Check for updates

The BMJ

Cite this as: BMJ 2021;375:n2733

http://dx.doi.org/10.1136/bmi.n2733

Published: 10 November 2021

\section{Covid vaccination to be mandatory for NHS staff in England from spring 2022}

\section{Abi Rimmer}

England's health and social care secretary has announced that all staff who work in health and social care settings regulated by the Care Quality Commission will have to be fully vaccinated against covid-19 by 1 April 2022.

Speaking in the House of Commons on 9 November, Sajid Javid said it could no longer be "business as usual" when it came to covid vaccines for health and social care staff. "All those working in the NHS and social care will have to be vaccinated," Javid said. "We must avoid preventable harm and protect patients in the NHS, protect colleagues in the NHS, and protect the NHS itself."

Javid said there would be exemptions for staff who do not have a face-to-face role with patients and those who are medically exempt from being vaccinated. He said the government had also decided against making the flu vaccine mandatory for NHS staff at this time but would keep this under review.

Javid said the policy for mandatory covid vaccination would be implemented through powers awarded to the government in the 2012 Health and Social Care Act, "which required registered persons to ensure the provision of safe care and treatment." He added that an impact assessment of the policy would be published before parliament voted on the change.

An analysis conducted by NHS Providers, which represents NHS trusts, found that around 103000 NHS workers were unvaccinated.

Data published by NHS England show that $93 \%$ of NHS trust healthcare staff ((1 350384 of 1453988$)$ have had their first dose of the covid vaccine and 90\% (1 307 832) have had their second, though the proportion varies across the country, and Javid said that in some trusts the figure was closer to $80 \% .^{1}$ In London, for example, NHS England data show that $84 \%$ of staff ( 172373 of 205776 ) have had both doses. The figures do not include agency workers or NHS bank staff.

Staff working in the adult social care sector are already required to have had both doses of the vaccine by 11 November to work in care homes in England regulated by the Care Quality Commission regulated, unless exempt. ${ }^{2}$

Responding to the report of mandatory vaccination for healthcare staff, a Department of Health and Social Care spokesperson said it had recently consulted on extending the requirements beyond social care staff. "We will set out our response in due course," the spokesperson said.

"Vaccines are safe and effective, and almost four in five people in the UK have already had both jabs to protect themselves against covid-19," the spokesperson added. "It's never too late to take up the offer, and we would urge everyone who is eligible to come forward as we head into the winter months."

Matthew Taylor, chief executive at the NHS Confederation, the membership body for organisations that provide or commission NHS services, welcomed the announcement and said that leaders would "take forward" a requirement for all staff to be vaccinated.

"Mandating covid-19 vaccinations in the NHS offers a further incentive for staff who are eligible but have not come forward yet to get jabbed at a time when the virus continues to be a threat and the NHS is working hard to deliver its broader services for patients," Taylor said. "For this reason, we are relieved the government has listened to our plea to roll out the requirement away from what is expected to be the most challenging winter on record.

However, other organisations have been less enthusiastic. In a statement issued last month Chaand Nagpaul, BMA council chair, said that the association had concerns about making vaccination mandatory. "One of the BMA's main concerns is the impact this decision may have on the workforce," he said. "Vaccination coverage among NHS workers is high . . However, even if a small number of staff were forced out of work because they are not vaccinated, this would have a big impact on a health service that's already under immense pressure."

The union Unite's national officer for health, Colenzo Jarrett-Thorpe, echoed these concerns about the requirement's effect on staffing levels. "The NHS is already seeing a severe recruitment and retention crisis ... and imposing a regime of mandatory vaccination will just exacerbate this crisis as we go into a very difficult winter for the health service, with an exhausted staff still battling the continuing 21 month old pandemic," he said.

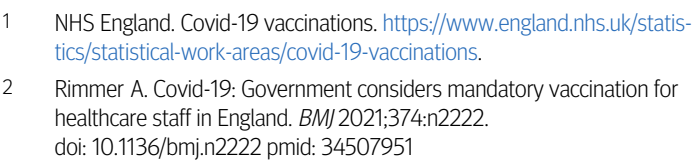

$1 \quad$ NHS England. Covid-19 vaccinations. https://www.england.nhs.uk/statistics/statistical-work-areas/covid-19-vaccinations.

2 Rimmer A. Covid-19: Government considers mandatory vaccination for healthcare staff in England. BMJ2021;374:n2222. doi: 10.1136/bmj.n2222 pmid: 34507951

This article is made freely available for use in accordance with BMJ's website terms and conditions for the duration of the covid-19 pandemic or until otherwise determined by BMJ. You may use, download and print the article for any lawful, non-commercial purpose (including text and data mining) provided that all copyright notices and trade marks are retained. 